\title{
空気集熱式太陽熱暖房システムの最適蓄熱槽容量に関する理論的検討 \\ THEORETICAL APPROACH TO OPTIMUM VOLUME OF ROCK BED FOR AIR-BASED SOLAR HEATING SYSTEM
}

\author{
北野博亮*, 相良和伸** \\ Hiroaki KITANO and Kazunobu SAGARA
}

\begin{abstract}
A theoretical approach to the optimum volume of rock bed and its charged thermal energy for an air-based solar heating system in charging mode is presented. The following results are obtained :

(1) As a result of system simulations, the charged thermal energy increases generally along with the increasing of rock bed volume, and the charged thermal energy has an upper limit corresponding to air flow rate. The minimum volume of roch bed which can be charged until almost upper limit is regarded as the optimum volume.

(2) The relationship between the optimum volume of rock bed and the air flow rate is approximately obtained as a solution of simultaneous equations for two models on the assumption of infinite flow rate or infinite rock bed volume, and this numerical solution is found to be linear approximately. It is found that the linear approximation model derived from these two models agrees well with the solution of simultaneous equations.
\end{abstract}

Keywords : solar energy, heating, thermal storage, rock bed, optimum volume 太陽エネルギー, 暖房, 蓄熱, 砕石蓄熱槽, 最適容量

\section{1.はじめに}

わが国の太平洋側地域では, 冬季の雲量は他の季節に比べ少なく, 例之ば東京では平均 $5 \sim 6$ 程度であり, 比較的日射量が多い1)。一方 で, 冬季に暖房・給湯用に利用されるエネルギーは, 住宅で消費さ れるエネルギーの約 3 分の 2 を占めることから, 太陽熱暖房には適 当な環境にあるといえる。しかしながら，冬季の暖房エネルギーを 太陽熱で賄ったとしても, 初期投資額を, 節約できたエネルギー費 で短期に償却することは必ずしも容易ではない。このため，太陽熱 暖房システムの最適設計は非常に重要となるが, 住宅設計に携わる 小規模な設計事務所では対応が難しいのが現状である。

太陽熱暖房システムの設計手法としては，シミュレーションによ る方法やf-chart 法等が提案されている2)。f-chart 法は, 数多くのシ ミュレーションの結果を整理したもので, 設計パラメータであるコ レクター面積, コレクターの種類, 蓄熱槽の容量, 熱媒の流量, - 熱 負荷等を設定すれば, 月毎の太陽熱依存率等が計算できるものであ る。f-chart 法およU゙シミュレーションによる方法では, 詳細な検討 が可能ではあるが, 設計パラメー夕の最適な組み合わせを得るため には，多くの設計パラメータの組み合わせについて，試行錯誤によ ク検討する必要があり，作業は煩雑である。

本研究では, 砕石蓄熱層を有する空気集熱式太陽熱暖房システム について，合理的な最適設計のための簡易な設計手法の開発を目的 とし, 蓄熱過程を对象とした場合の風量と最適蓄熱槽容量の関係, およびそのときの蓄熱量について，理論的検討を行った。

\section{2. 対象システムと設定条件}

对象としたシステムは, その概略を図 1 に示したような, 平板型 コレクター, 䂶石蓄熱槽, ファンから構成される空気集熱式太陽熱 暖房システムの集熱システム部分である。基本的な設定条件を表 1 に示した。ここでは, 暖房期間全体の太陽熱依存率とコストのバラ ンスから, 最も寒い時期の晴天日の日射量でその日の負荷が賄える 程度のシステムがシステムの規模として適当であるという仮定に基 づき, 気象条件として東京の真冬（2月1日）の晴天日を例として 検討している。なお, コレクターの方位角を 0 (真南), 外気温度は $0{ }^{\circ} \mathrm{C}$ で終日一定と仮定した。コレクター面への日射量は, Bouguer の直達日射量の式と Berlageの天空日射量の式から計算される值 を用いた4)。砕石蓄熱槽は, 熱媒空気の流れ方向が鉛直方向となるよ

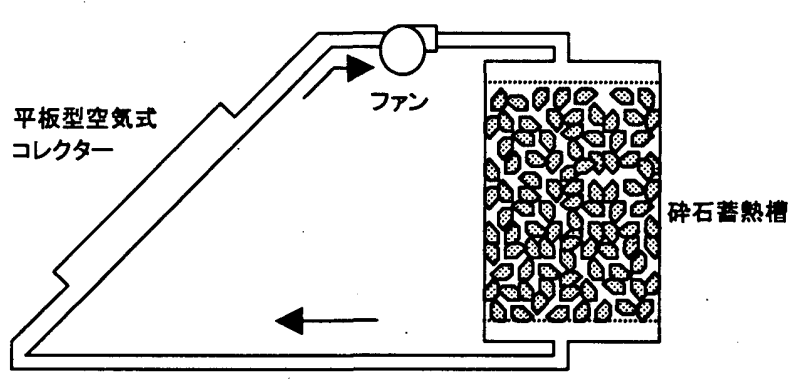

図 1 システムの概略図

\footnotetext{
* 三重大学工学部建築学科 助手・修士 (工学) Research Assoc., Dept. of Architecture, Faculty of Engineering, Mie University, ** 三重大学工学部建築学科 教授. 工博 M. Eng. Prof., Dept. of Architecture, Faculty of Engineering, Mie University, Dr. Eng.
} 
表 1 設定条件

\begin{tabular}{|c|c|}
\hline 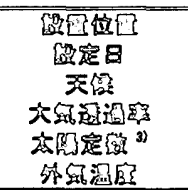 & 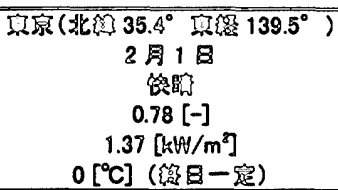 \\
\hline \multicolumn{2}{|c|}{ コレクター } \\
\hline 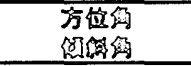 & 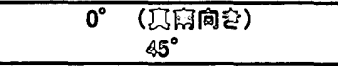 \\
\hline \multicolumn{2}{|c|}{ ファン } \\
\hline 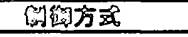 & 三全气的约 \\
\hline \multicolumn{2}{|c|}{ 5m } \\
\hline 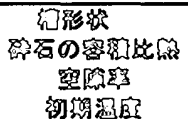 & 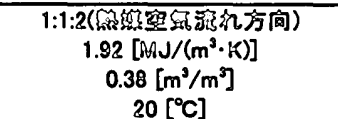 \\
\hline
\end{tabular}

效 2 コレクターの特性と仕様

\begin{tabular}{|c|c|c|c|}
\hline & コレクターA & コレクターB & コレクターC \\
\hline$F^{\prime} K_{c o l}\left[N /\left(m^{2} \cdot K\right)\right]$ & 3.37 & 5.42 & 7.48 \\
\hline$F^{\prime}(\varepsilon \alpha)_{2}[-]$ & 0.76 & 0.68 & 0.65 \\
\hline 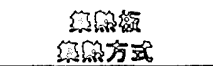 & 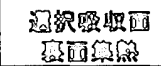 & 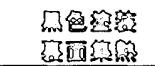 & 员绝管 \\
\hline
\end{tabular}

うに設置し, 形状は水平断面が正方形の直方体で, 高さは水平断面 の辺の二倍とした。蓄熱槽内初期温度は， $20^{\circ} \mathrm{C}$ 一様としているが, これは暖房時に放熱が完了した時点で，槽内が暖房設定温度付近と なっているとしているためである。

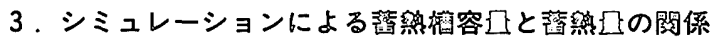

3.1 シミュレーションの天デル

集熱・蓄熱特性の把握のため，コレクターのモデルと砕石蓄熱槽 の伝熱モデルを用いて数值計算を行った。なお，コレクター以外で の熱損失とファンや摩擦による熱取得は相殺されるものと仮定し, これらの影響は無視している。

[コレクター]

平板形コレクターの集熱効率の式として，太陽熱暖房システムの シミュレーションに一般に用いられている Hottel·Whillier の一次 の定義式4を用いた。この式は，集熱板での受熱量から熱損失量を差 し引いた正味の集熱量と日射量の比として次式で定義される。

$$
\eta=F^{\prime}(\tau \alpha)_{e}-F^{\prime} K_{c o l} \frac{\left(\theta_{c o l, \text { in }}+\theta_{c o l, o u t}\right) 0.5-\theta_{a m b}}{I}
$$

シミュレーションに用いた三種のコレクターの特性係数およU゙そ の仕様を表 2 に示した。これらの特性係数は, 田中等 ${ }^{5}$ の実験結果の 図から読み取った値である。なおこれらの特性係数は,コレクター の面積が $2.03 \mathrm{~m}^{2}$, 風量が約 $120 \mathrm{~m}^{3} / \mathrm{h}$ で測定されたものであるが，こ こでは，風量，長波長放射および日射のコレクタ一面への入射角度 の影響はなく定数と仮定している。一般に，式(1)中の $F^{\prime * 1}$ は風量の 影響を受け、コレクターの性能試験時と異なる風量を使用する場合 には，補正する必要がある。しかし，風量の影響を考慮したモデル と本論文で用いたモデルとの比較では，その影響は比較的小さく ${ }^{6)}$, 簡易な設計手法の開発を目的としている本研究では, $F^{\prime}$ の風量依存 性は無視できると仮定している。また，コレクター自体の熱容量の 影響も考慮していないが, 日射量に急激な変化のない晴天の条件下 では，コレクターの熱容量が集熱量へ与える影響は無視できる程度 である゙。
また，コレクターの集熱効率はコレクターの出入口空気温度差を 用いて，集熱量と日射量の比から次式のようにも表現できる。

$$
\eta=\frac{c_{a i r} \rho_{a i r} F_{a}\left(\theta_{c o l, o u t}-\theta_{c o l, \text { in }}\right)}{I A_{\text {col }}}
$$

式(1)と(2)から，コレクターの出入口空気温度 $\left(\theta_{c o l, o u t}\right)$ を得るコレ クターのモデル式は，次式となる。

$$
\theta_{c o l, o u t}=\frac{\left(\frac{c_{a i r} \rho_{a i r} F_{a}}{F^{\prime} K_{c o l} A_{c o l}}-0.5\right) \theta_{c o l, i n}+\frac{F^{\prime}(\tau \alpha)_{e}}{F^{\prime} K_{c o l}} I+\theta_{a m b}}{\frac{c_{a i r} \rho_{a i r} F_{a}}{F^{\prime} K_{c o l} A_{c o l}}+0.5}
$$

\section{[碚石篦鶖诲]}

砕石蓄熱槽の伝熱モデルは, Schumann ${ }^{8}$ によって提案されたモデ ルを用いた。Schumann モデルは以下の仮定に基づいている。

(1) 蓄熱材として小径の砕石を想定しているので，蓄熱材内部の 温度は一様である。

（2）槽内空気は一次元流れであり，流速分布は断面全体にわたっ て一様である。

（3）槽内空気の流れ方向の熱移動は空気の移流によるものだけを 考慮し，熱伝導，放射等による熱移動は無視する。

（4）蓄熱層からの熱損失はない。

さらに, Schumann モデルの蓄熱槽内空気の熱収支式に関して， 空気の熱容量は砕石に比べ十分小さいのでこれを無視できるとする と，蓄熱槽内空気および砕石の熱収支式は，式(4)，式(5)となる9)。

$$
\begin{aligned}
& c_{a i r} \rho_{a i r} F_{a} \frac{\partial \theta_{s t, a i r}}{\partial x}=h_{v} A_{s t}\left(\theta_{s t, s}-\theta_{s t, a i r}\right) \\
& c_{s t, s} \rho_{s t, s} A_{s t}(1-f) \frac{\partial \theta_{s t, s}}{\partial t}=h_{v} A_{s t}\left(\theta_{s t, a i r}-\theta_{s t, s}\right)
\end{aligned}
$$

ここで，体積熱伝達率 $h_{v}$ は，次式の值を用いた ${ }^{10)}$ 。

$$
h_{v}=700\left(\frac{F_{a} \rho_{a i r}}{A_{s t} d_{e}}\right)^{0.76}
$$

一日の蓄熱量（ $\left.Q_{s}\right)$ の計算にあたって，まず，式(4)，(5)を有限差 分法を用いて, 集熱開始時から計算を始め, 集熱終了時の蓄熱槽内 の空気と砕石の温度分布を求めた。ここでは, 砕石蓄熱槽を空気の 流れ方向に20分割, 時間ステップを1.0secとし, 砕石蓄熱槽の空気 の流入側境界条件である入口空気温度は日射量とコレクターへの入 口空気温度 $\left(\theta_{c o l, i n}\right)$ (=砕石蓄熱槽の出口空気温度) 等から式(3)を用 いて計算している。なお，集熱条件としては，コレクターの入口空 気温度 $\left(\theta_{c o l, i n}\right)$ よりも出口空気温度 $\left(\theta_{c o l, o u t}\right)$ が高くなるときに集 熱するものとした。つまり，

$$
\theta_{c o l, \text { in }}<\theta_{\text {col,out }}
$$

となるときである。式(7)の条件式は，式(3)を用いて日射量に関して 表すと,

$$
I>\frac{F^{\prime} K_{c o l}\left(\theta_{c o l, i n}-\theta_{a m b}\right)}{F^{\prime}(\tau \alpha)_{e}}
$$

となる。一日の蓄熱量 $\left(Q_{s}\right)$ は, 集熱終了時の蓄熱槽内温度から, 次式で求まる。

$$
Q_{s}=c_{s t, s} \rho_{s t, s}(1-f) \int_{V_{s t}}\left(\left.\theta_{s t, s}\right|_{t=t e n d}-\theta_{o}\right) d V
$$

ただし，蓄熱槽内空気の熱容量は，砕石に比べ十分小さいので無視 できるとしている。 


\section{2 計算結果と最適蓄熱槽容量}

図 2 は,コレクター単位面積あたりの一日の蓄熱量の計算結果で あり，コレクター単位面積あたりの蓄熱槽容量との関係を，コレク ター単位面積当たりの風量をパラメータとして表したものである。 （以下では，単に蓄熱量, 蓄熱槽容量; 風量と呼ぶ。）なお, この四 はコレクター面積が $10 \mathrm{~m}^{2}$ の場合の結果であるが, コレクター面積が 異なる場合であってもほぼ同様の結果が得られる。それぞれのコレ クターの一日の蓄熱量は, 蓄熱槽容量の増大にしたがって, 風量に 関わらず同じ曲線に沿って増大し，ある蓄熱量に達すると，それ以 上蓄熱槽容量が増しても蓄熱量は増えず，それぞれの風量に応じた 一定值となる。一般的に，蓄熱槽容量が大きくなるほど槽出口空気 温度 (ニコレクター入口空気温度 $\left.\left(\theta_{c o l, i n}\right)\right)$ は上年し難くなるため, 集熱効率が高くなり蓄熱量が大きくなるが，槽出口空気温度は槽内 初期温度（ $\left.\theta_{0}\right)$ 以下にはならないので, ある蓄熱量以上には増大し ない。この蓄熱量を以下では限界蓄熱量と呼ぶ。また，風量が増大 するにしたがってコレクター出口空気温度が上䄯し難くなるため に，集熱効率が高くなり，この限界蓄熱量は増大することになる。

図 3 は, コレクターBの場合で，風量が $40\left(\mathrm{~m}^{3} / \mathrm{h}\right) / \mathrm{m}^{2}$, 蓄熱槽容

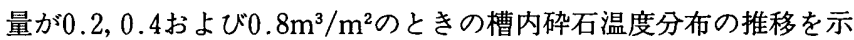
したものである。なお，図 3 (1)，(2)，(3)は，それぞれ，図2におけ る(1)，(2)，(3)の条件に対応している。蓄熱槽容量が $0.8 \mathrm{~m}^{3} / \mathrm{m}^{2} て ゙ は ，$ 蓄熱槽の下部に蓄熱に利用されない部分が残るのが分かる。

これらのシミュレーション結果から，本論文では，限界蓄熱量を ほぼ蓄熱できる最小の蓄熱槽容量を容量効率の観点から見た最適蓄 熱槽容量と定義する。もちろん, 本来の最適蓄熱槽容量は, 放熱モ一 ドを含めたエネルギー効率やコスト等を考慮したものでなければな らないが，本研究での最適蓄熱槽容量以上に大きくしても蓄熱量が 增大しないことから，蓄熱槽容量の上限を規定していると考えるこ ともできる。なお，本研究のコレクターモデルでは，コレクターで の熱損失に放射の影響を無視していること，そして風量のコレク ターの特性係数に与える影響を考慮していないことから，極端に蓄 熱槽容量が小さく集熱温度が高温になる条件や風量が性能試験時の 風量に比較して極端に小さい場合では，本シミュレーション結果の 蓄熱量を実際には蓄熱できないことに注意が必要である。

\section{4 . 極限モデルの連立解による風量と最適蓄熱槽容量の関係}

困 2 に示した各風量での蓄熱槽容量と蓄熱量の関係を表す特性曲 線は, 最適蓄熱槽容量付近を境に二つの部分に分けることができる。 つまり, 蓄熱槽容量の增加に伴って風量に関わらず同じ曲線上にそっ て蓄熱量が増大する部分と蓄熱槽容量に関わらず蓄熱量が一定の値 となる部分である。本研究では，これら二つの状態を以下のように 極限状態を想定してモデル化し，これらの二式の連立解として風量 と最適蓄熱槽容量の関係とそのときの蓄熱量を得るための理論的な 検討を行った。これらの極限モデルは, 実際には存在し得ない条件の モデルであるが, これらのモデルは，ここでいう最適蓄熱槽容量の 近似值を理論的に求めるためのモデルとして導出されたものである。

\section{1 極限モデル}

蓄熱槽容量と蓄熱量の関係が風量に関係しない部分に対しては, 無限風量を想定して蓄熱槽容量と蓄熱量の関係をモデル化した。一 方，蓄熱槽容量に関わらず蓄熱量が各風量で一定值となる部分に对

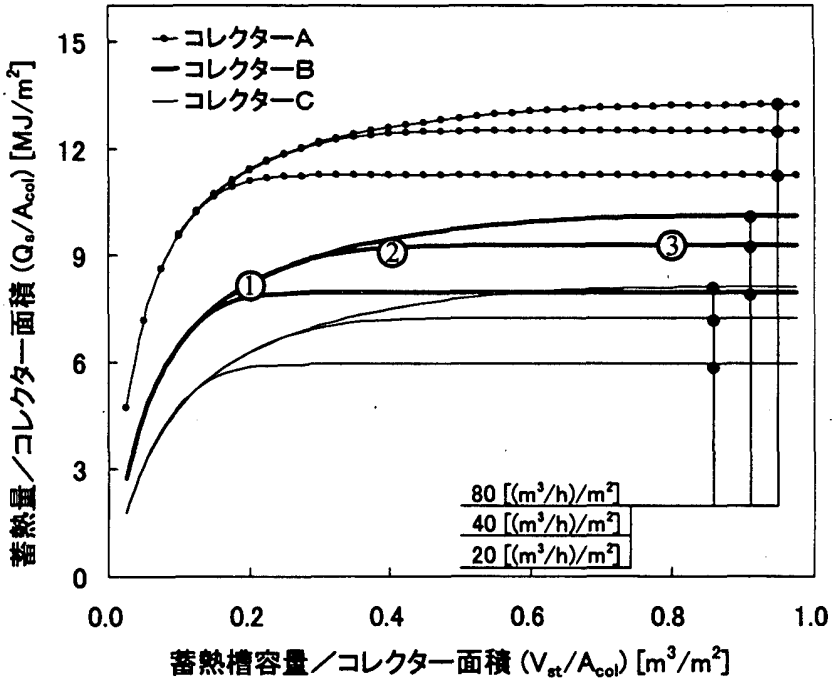

図 2 シミュレーションによるコレクター単位面樻あたりの蓄熱槽容量と蓄 熱量の関係

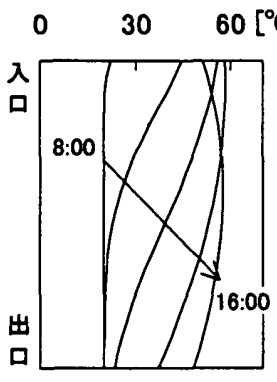

(1) $V_{u t} / A_{c o l}=0.2\left[\mathrm{~m}^{2} / \mathrm{m}^{2}\right]$

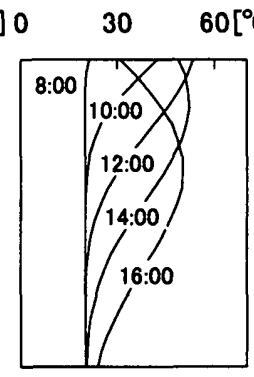

(2) $V_{t t} / A_{c o t}=0.4\left[\mathrm{~m}^{3} / \mathrm{m}^{2}\right]$

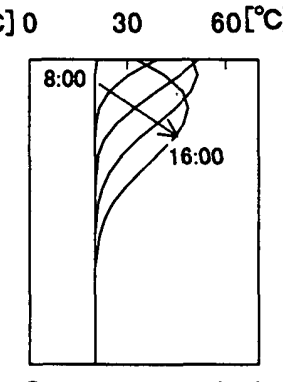

(3) $V_{n 1} / A_{\infty o l}=0.8\left[\mathrm{~m}^{3} / \mathrm{m}^{2}\right]$
図 3 蓄熱槽内の砕石温度分布の推移の例 (コレクターB,$\left.\quad F_{a} / A_{c o l}=40\left(\mathrm{~m}^{3} / \mathrm{h}\right) / \mathrm{m}^{2}\right)$ の場合

しては, 無限蓄熱槽容量を想定して風量と限界蓄熱量との関係をモ デル化した。ここでは, それぞれのモデルを無限風量モデル, 無限 蓄熱槽容量モデル，またはこれらをまとめて極限モデルと呼ぶこと とする。

\section{（1） 無限風量モデル}

蓄熱量が風量に関係しない部分の蓄熱量と蓄熱槽容量の関係式 は, 無限風量を想定し, 次のように仮定して導出した。 [無限風量モデルの仮定］

(1) 槽内の空気温度と砕石温度, コレクタ一内の空気温度は等しい。

(2) コレクターで集熱された熱はすべて蓄熱される。

（3）蓄熱量の計算に際して，空気の熱容量は無視する。

風量が相対的に大きい場合には，コレクター出入口での熱媒空気 の温度差は小さく, 砕石蓄熱槽内の温度分布がほぼ一様となると考 えられることから, 無限風量モデルでは, 仮定(1)ように, 槽内の 空気温度, 砕石温度およびコレクタ一内の空気温度は等しいと仮定 し, 風量無限大の条件下での蓄熱槽容量と蓄熱量の関係をモデル化 している。

コレクターでの集熱量（ $\left.q_{c o l}\right)$ は，仮定(1)と式(1)とから，

$$
q_{c o l}=F^{\prime}(\tau \alpha)_{e} A_{c o l} I-F^{\prime} K_{c o l} A_{c o l}\left(\theta_{s t, s}-\theta_{a m b}\right)
$$

となるので，蓄熱槽の熱収支式は，仮定(2)，(3)およU゙式(5)，式(10)か 
ら次式となる。

$$
c_{s t, s} \rho_{s t, s}(1-f) V_{s t} \frac{d \theta_{s t, s}}{d t}
$$

$=F^{\prime}(\tau \alpha)_{e} A_{c o l} I-F^{\prime} K_{c o l} A_{c o l}\left(\theta_{s t, s}-\theta_{a m b}\right)$

一方, 一日の蓄熱量は, 集熱開始時刻 $\left(t_{s t a r t}\right)$ と集熱終了時刻 $\left(t_{F_{\text {end }}}\right)$ での蓄熱槽内温度の変化量から,

$Q_{s}=c_{s t, s} \rho_{s t, s}(1-f) V_{s t}\left(\left.\theta_{s t, s}\right|_{t=t_{\text {fent }}}-\theta_{o}\right)$

で表される。式(11)の一階常微分方程式を, 初期条件 $\left(\theta_{s t, s}=\theta_{o}\right)$ のも とで解いて，日射量に関する積分を残したまま式(12)に代入すると， コレクター単位面積あたりの蓄熱量 $\left(Q_{s} / A_{c o l}\right)$ は,

$$
\begin{aligned}
& \frac{Q_{s}}{A_{c o l}}=F^{\prime}(\tau \alpha)_{e} \exp \left[-\alpha_{s}\left(t_{F_{e n d}}-t_{s t a r t}\right)\right] \int_{t_{s t a r t}}^{t_{\text {Fena }}} I \exp \left[\alpha_{s} t\right] d t \\
& \quad+c_{s t, s} \rho_{s t, s}(1-f) \frac{V_{s t}}{A_{c o l}}\left\{1-\exp \left[-\alpha_{s}\left(t_{F_{e n d}}-t_{s t a r t}\right)\right]\right\} \\
& \quad \times\left(\theta_{a m b}-\theta_{o}\right)
\end{aligned}
$$

と表すことができる。ここで $\alpha_{s}$ は，

$$
\alpha_{s}=\frac{F^{\prime} K_{c o l}}{c_{s t, s} \rho_{s t, s}(1-f)} \frac{A_{c o l}}{V_{s t}}
$$

である。

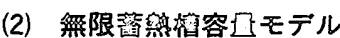

一方, 風量とその限界蓄熱量の関係式は, 蓄熱槽容量が無限大の 場合を想定し，次のように仮定して導出した。

[無限蓄熱槽容量モデルの仮定]

(1) 無限蓄熱槽容量の場合には, 槽内温度の上昇は槽入口部分に限 られるため，槽出口温度は槽内初期温度と等しい。

(2) コレクターで集熱された熱はすぺて蓄熱される。

一日の蓄熱量 $\left(Q_{s}\right)$ は，仮定(1)(2)から，コレクターでの集熱量を 集熱開始時刻 $\left(t_{\text {start }}\right)$ から終了時刻 $\left(t_{\text {Vend }}\right)$ まで積分することで計算 できる。

$$
Q_{s}=c_{a i r} P_{a i r} F_{a} \int_{t_{s t a r t}}^{t_{\text {vera }}}\left(\theta_{c o l, o u t}-\theta_{o}\right) d t
$$

この式(15)にコレクターの入口空気温度を蓄熱槽内初期温度 $\left(\theta_{o}\right)$ とした場合の式(3)を代入し，日射量の積分を残したまま積分を実行 すると、コレクター単位面積あたりの蓄熱量 $\left(Q_{s} / A_{c o l}\right)$ は,

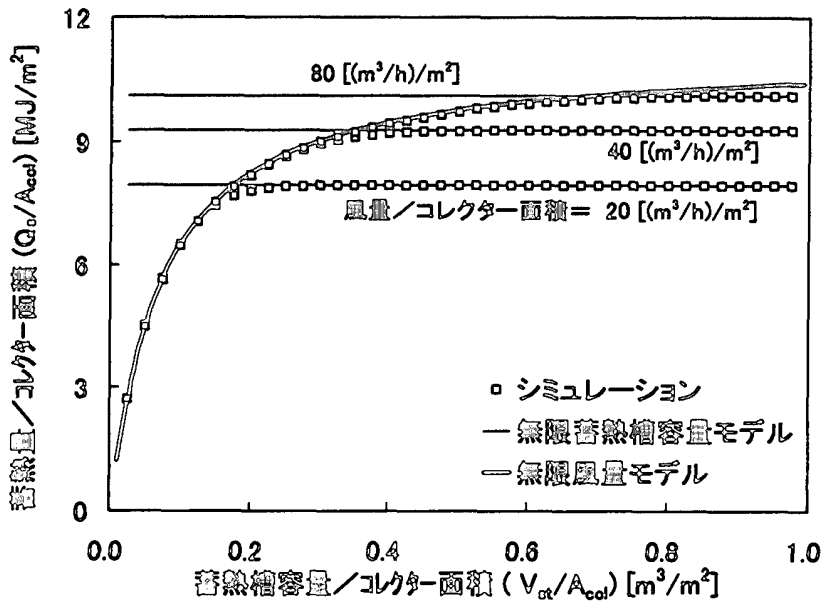

图 4 シミュレーションとニつの極限モデルによる蓄熱槽容量と蓄熱量の関 係 (コレクターB)

$$
\begin{aligned}
\frac{Q_{s}}{A_{c o l}}= & \frac{\frac{F_{a}}{A_{c o l}}}{\frac{F_{a}}{A_{c o l}}+\frac{1}{2} \frac{F^{\prime} K_{c o l}}{C_{a i r} \rho_{a i r}}}\left\{F^{\prime}(\tau \alpha) e \int_{t_{\text {start }}}^{t_{\text {vond }}} I d t\right. \\
& \left.-F^{\prime} K_{\text {col }}\left(\theta_{o}-\theta_{\text {amb }}\right)\left(t_{v_{\text {end }}}-t_{\text {start }}\right)\right\}
\end{aligned}
$$

となる。式(16)を用いることによって，風量が決まればそのときの限 界蓄熱量を求めることができることになる。

\section{2 㥛限モデルの解法}

無限風量モデル（式(13)）の集熱条件は，無限風量モデルの仮定(1) から, 式(8)でコレクター入口空気温度を砕石温度とした集熱条件式 で表されることになるので，集熱終了時刻 $\left(t_{F \text { end }}\right)$ を決定するために はそのときの砕石温度を知る必要がある。よって，集熱終了時刻を 前もって決定するのは困難であり，また，日射に関する積分にモデ ル式の変数である蓄熱槽容量 $\left(V_{s t}\right)$ を含むため, 式(13)を直接解くの も图難である。そこで, 無限風量モデルでは, 式(11)に蓄熱槽容量 $\left(V_{s t}\right)$ を与え, 計算時間間隔を60秒とし，それぞれの時刻に対応した日射 量を与えて, 数值計算により解いて条件を満たす最終の時刻の砕石 温度を計算し，この砕石温度を式(12)に代入して蓄熱量を計算してい る。なお, 無限風量モデルとして最終的に得られた式(13)は次節で線 形近似モデルの導出のために用いている。

一方，無限蓄熱槽容量モデル（式(16)）については，無限蓄熱槽容 量モデルの仮定(1)から，式(8)のコレクター入口空気温度 $\left(\theta_{c o l, i n}\right)$ を 蓄熱槽初期温度（ $\left.\theta_{0}\right)$ に置き換えた次式の集熱条件式を用いて集熱 開始・終了時刻を求め, 計算に必要な積算日射量は60秒の計算タイ ムステップで台形法を用いて数值積分して求めている。

$$
I>\frac{F^{\prime} K_{c o l}\left(\theta_{o}-\theta_{a m b}\right)}{F^{\prime}(\tau \alpha)_{e}}
$$

これら二つの極限モデルの連立解については, 無限蓄熱槽容量モ デル（式(16)）に風量を代入して蓄熱量を計算し，次に，無限風量モ デル（式(11)，(12)）において，蓄熱量が式(16)の解と等しくなる蓄熱槽 容量を, 二分法により蓄熱量の差が $0.01 \mathrm{~J} / \mathrm{m}^{2}$ 以下になるまで収束計 算し，そのときの蓄熱槽容量を最適蓄熱槽容量として得ている。

\section{3 極限テデルの通立解}

图 4 に示した二つの極限モデルとシミュレーションによる蓄熱量 と蓄熱槽容量の関係から，二つの極限モデルの交点として得られる 蓄熱量は, シミュレーションで計算される実際の蓄熱量よりも若干 多めとなるが，その差はわずかであり，風量に応じて決まる限界蓄 熱量をほぼ蓄熱できる最適蓄熱槽容量を良く近似できていることが 分かる。

極限モデルの連立解として得られる風量と最適蓄熱槽容量の関係 を図 5 に示す。この図から，風量と最適蓄熱槽容量はほほ線形関係 であること，またコレクターの性能によって蓄熱量は大きく異なる ものの最適蓄熱槽量の差は微少であることが分かる。

\section{5. 缐形近似モデル}

極限モデルの連立解として得られる風量と最適蓄熱槽容量の関係 がほほ線形関係であることから，ここでは，無限風量モデルと無限 蓄熱槽容量モデルから，図 5 に示した風量と最適蓄熱槽容量の関係 の線形近似モデルを導出する。風量と最適蓄熱槽容量の関係式は, 式(13)，(16)から蓄熱量 $\left(Q_{s} / A_{c o l}\right)$ を消去して, 蓄熱槽容量 $\left(V_{s t} / A_{c o l}\right)$ を最適蓄熱槽容量 $\left(V_{o p t} / A_{c o l}\right)$ に置き換えると，最適蓄熱槽容量と 


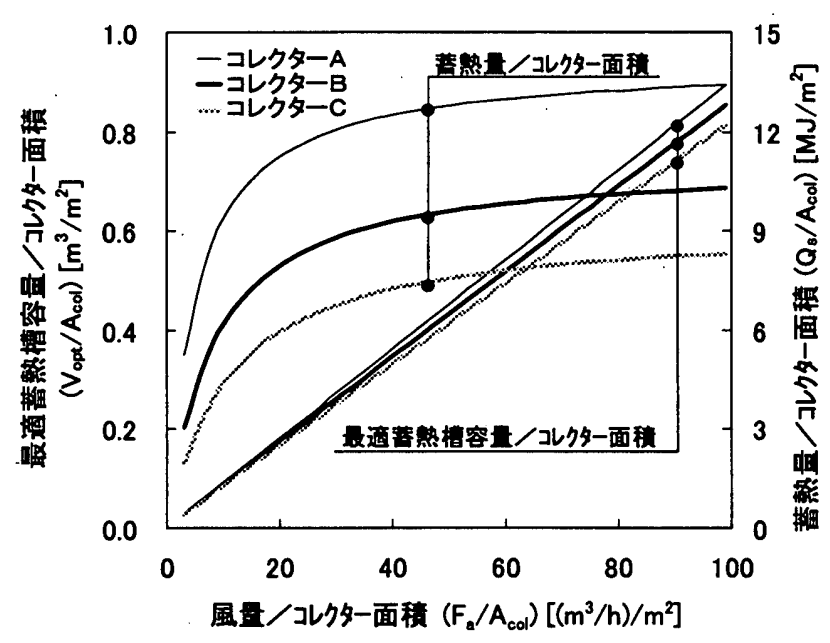

图 5 二つの極限モデルの連立解による風量と最適蓄熱槽容量および蓄熱量 の関係

風量 $\left(F_{a} / A_{c o l}\right)$ を見かけ上, 線形関係として次式で表わすことがで きる。

$$
\frac{V_{o p t}}{A_{c o l}}=P \frac{F_{a}}{A_{c o l}}
$$

ここで, 比例係数である $P$ は, 実際には定数ではなく $V_{o p t}, A_{c o l}$, $I, t_{\text {start }}, t_{\text {Fend }}, t_{V_{\text {end }}}$ 等の関数であり, 次式のような複雑な式となっ ている。

$$
\begin{aligned}
P & =\frac{2 c_{a i r} \rho_{a i r}}{F^{\prime} K_{c o l} D_{\left(V_{o p t}\right)}}\left\{F^{\prime}(\tau \alpha)_{e} \frac{V_{o p t}}{A_{\text {col }}} \int_{t_{\text {start }}}^{t_{\text {vent }}} I d t\right. \\
& \left.\left.-F^{\prime} K_{\text {cor }} \frac{V_{o p t}}{A_{c o l}}\left(\theta_{o}-\theta_{a m b}\right)\left(t_{V_{\text {end }}}-t_{\text {start }}\right)-D_{\left(V_{\text {opt }}\right)}\right) \frac{V_{o p t}}{A_{\text {col }}}\right\}
\end{aligned}
$$

ここで, 式中の $D_{\left(v_{o p t}\right)}$ は,

$$
\begin{aligned}
& D_{\left(V_{\text {opt }}\right)}=F^{\prime}(\tau \alpha)_{e} \int_{t_{s t a r t}}^{t_{\text {fent }}} I \exp \left[\frac{F^{\prime} K_{\text {col }}}{c_{s t, s} \rho_{s t, s}(1-f)} \frac{A_{\text {col }}}{V_{o p t}}\left(t-t_{\text {Fend }}\right)\right] d t \\
& -c_{s t, s} \rho_{s t, s}(1-f) \frac{V_{o p t}}{A_{c o l}}\left(\theta_{o}-\theta_{a m b}\right) \\
& \times\left(1-\exp \left[-\frac{F^{\prime} K_{c o l}}{c_{s t, s} \rho_{s t, s}(1-f)} \frac{A_{c o l}}{V_{o p t}}\left(t_{F_{\text {end }}}-t_{\text {start }}\right)\right]\right)
\end{aligned}
$$

である。図 5 の極限モデルの計算結果から明らかなように, この $P$ は最適蓄熱槽容量や風量等に関わらず，近似的には一定値としてよ いと考えられる。そこで, 指数項を級数展開して, 微小項を無視す ると共に, 無限風量モデルの集熱終了時刻 $\left(t_{\text {Fend }}\right)$ は無限蓄熱槽容量 モデルの集熱終了時刻 $\left(t_{\text {Vend }}\right)$ に等しいと仮定して，その時刻を $t_{\text {lend }}$ としたときの $P$ の值を $P_{l}$ とすると, $P_{l}$ は,

$$
\begin{aligned}
& P_{l}=\frac{c_{a i r} \rho_{a i r}}{c_{s t, s} \rho_{s t, s}(1-f)} \\
& \times \frac{2 F^{\prime}(\tau \alpha)_{e} \iint_{t_{\text {start }}}^{t_{\text {tera }}} I d t-F^{\prime} K_{c o l}\left(\theta_{o}-\theta_{a m b}\right)\left(t_{\text {lend }}-t_{\text {start }}\right)^{2}}{F^{\prime}(\tau \alpha)_{e} \int_{t_{\text {start }}}^{t_{\text {teat }}} I d t-F^{\prime} K_{c o l}\left(\theta_{o}-\theta_{a m b}\right)\left(t_{\text {lend }}-t_{\text {start }}\right)}
\end{aligned}
$$

のように, 蓄熱槽容量, 風量およびコレクタ一面積に関わらず, コ レクターと砕石蓄熱槽の特性および日射量で決まる定数として近似 化できる。ここで, 集熱開始および終了時刻は, 無限蓄熱槽容量モ デルと同様に，式(17)ら決定するものとする。

さらに，コレクターの方位角を 0 ○ (真南) に設定しているので,
赤緯の日変動を無視すると, コレクタ一へ入射する日射量と集熱時 間は，真太陽時で12：00を軸にして対称であることから，日射に関 する二重積分は,

$$
\iint_{t_{\text {start }}}^{t_{\text {tena }}} I d t=\frac{t_{l_{\text {lend }}}-t_{\text {start }}}{2} \int_{t_{\text {start }}}^{t_{\text {lena }}} I d t
$$

とできる。これを式(21)に代入すると，Pl は簡単に,

$$
P_{l}=\frac{c_{a i r} \rho_{a i r}\left(t_{\text {lend }}-t_{\text {start }}\right)}{c_{s t, s} \rho_{s t, s}(1-f)}
$$

となり，最適蓄熱槽容量と風量の関係を式(24)のように単純な線形関 係で表現できる（以下，線形近似モデル)。

$$
\frac{V_{o p t}}{A_{c o l}}=\frac{c_{a i r} \rho_{a i r}\left(t_{\text {lend }}-t_{\text {start }}\right)}{c_{s t, s} \rho_{s t, s}(1-f)} \frac{F_{a}}{A_{c o l}}
$$

最終的に得られたこの関係式は，蓄熱時に蓄熱槽を通過する熱媒 㞬気の総熱容量に槽内の熱容量が等しくなる蓄熱槽容量が最適蓄熱 槽容量であることを表している。

図 6 に示した線形近似モデルの解と極限モデルの数值連立解か ら，線形近似モデルは風量と最適蓄熱槽容量の関係を精度良く近似 できていることが分かる。

これらの結果（式(16)，式(24)）は，日射量，負荷に見合った蓄熱量 等が設計条件として与えられたときに，この蓄熱量を確保できる容 量効率の観点から見た最適蓄熱槽容量, 風量およびコレクター面積 の関係を表している。設計条件として，日射量，外気温度，コレク ターの特性等が与えられれば，式(17)から集熱時間が求まり，結果と して式(16)に用いる積算日射量が求まる。次に，風量を設定すれば, 蓄熱量が与えられているので, 式(16)から必要コレクター面積が計算 でき，式(24)から蓄熱槽容量を決定できる。例之ば，表1に示した条 件で，表 2 のコレクターB を用いた場合に，負荷に見合った蓄熱量 を $100 \mathrm{MJ}$ とし, コレクター単位面積当たりの風量を $30\left(\mathrm{~m}^{3} / \mathrm{h}\right) / \mathrm{m}^{2}$ と すると,コレクター面積は $11.4 \mathrm{~m}^{2}$ となり, 最適蓄熱槽容量は $2.9 \mathrm{~m}^{3}$ と なる。なお，日々の暖房負荷に見合ったコスト的にも最適な蓄熱量 や日射量をどのような条件に設定するのが適当であるかは，今後，

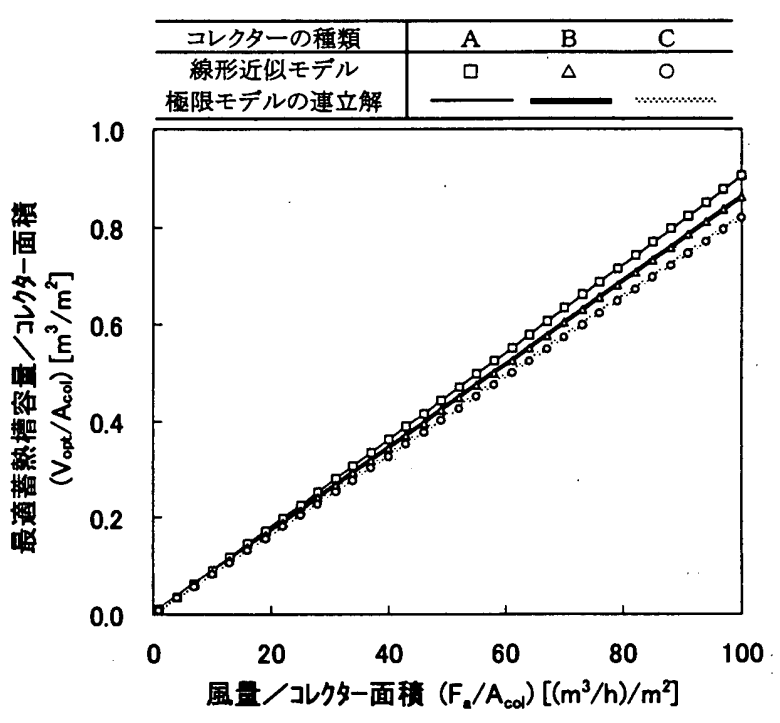

图 6 二つの極限モデルおよび線形近似モデルによる風量と最適蓄熱槽容量 の関係と無限蓄熱槽容量モデルによるそのときの蓄熱量 
表 3 各パラメータが変化した場合の，式(16)のから近似的に計算される蓄熱量およびその蓄熱量とシミュレーションにより 計算される蓄熱量との誤差

\begin{tabular}{|c|c|c|c|c|c|}
\hline & & \multicolumn{4}{|c|}{ 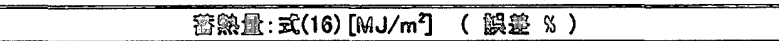 } \\
\hline \multicolumn{2}{|c|}{ 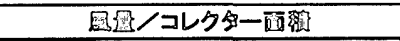 } & $20\left[\left(\mathrm{~m}^{3} / \mathrm{h}\right) / \mathrm{m}^{2}\right]$ & $\Delta 0\left[\left(\mathrm{~m}^{3} / \mathrm{h}\right) / \mathrm{m}^{2}\right]$ & \multicolumn{2}{|c|}{$80\left[\left(\mathrm{~m}^{3} / \mathrm{h}\right) / \mathrm{m}^{2}\right]$} \\
\hline \multicolumn{2}{|c|}{ 迎实烦佟 } & $7.05 \quad(-3.578)$ & 9.28 ( $(-1.855)$ & 80.01 & $(40.809)$ \\
\hline \multirow{2}{*}{ 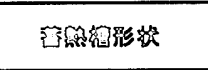 } & 1:1:1(桼さ) & $7.95(+8.86 \%)$ & $9.28 \quad(+2.52 \%)$ & 10.12 & $(+1.22 \%)$ \\
\hline & 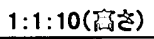 & $7.95(+1.65 \%)$ & $9.28 \quad(+0.85 \%)$ & 10.12 & $(+0.40 \%)$ \\
\hline \multirow{2}{*}{ コレクター面烈 } & $5.0\left[\mathrm{~m}^{2}\right]$ & $7.95(+4.17 \%)$ & $9.28(+2.17 \%)$ & 10.12 & $(+1.08 \%)$ \\
\hline & $80.0\left[\mathrm{~m}^{2}\right]$ & $7.95 \quad(+2.59 \%)$ & $9.28 \quad(+1.38 \%)$ & 10.12 & $(+0.68 \%)$ \\
\hline \multirow{2}{*}{ 外路瀑绍 } & $5\left[{ }^{\circ} \mathrm{C}\right]$ & $8.55(+3.50 \%)$ & $9.97(+1.82 \%)$ & 10.87 & $(+0.87 \%)$ \\
\hline & $10\left[{ }^{\circ} \mathrm{C}\right]$ & $9.16(\$ 3.41 \%)$ & $10.68 \quad(+1.77 \%)$ & 11.65 & $(+0.85 \%)$ \\
\hline \multirow{2}{*}{ コレクミーの方位的 } & $\$ 10^{\circ}$ & $7.87(+3.81 \%)$ & $9.18 \quad(+1.76 \$)$ & 10.02 & $(+0.8 \& \$)$ \\
\hline & $-10^{\circ}$ & $7.87(+3.78 \%)$ & $9.18(+1.96 \%)$ & 10.02 & $(+0.95 \%)$ \\
\hline
\end{tabular}

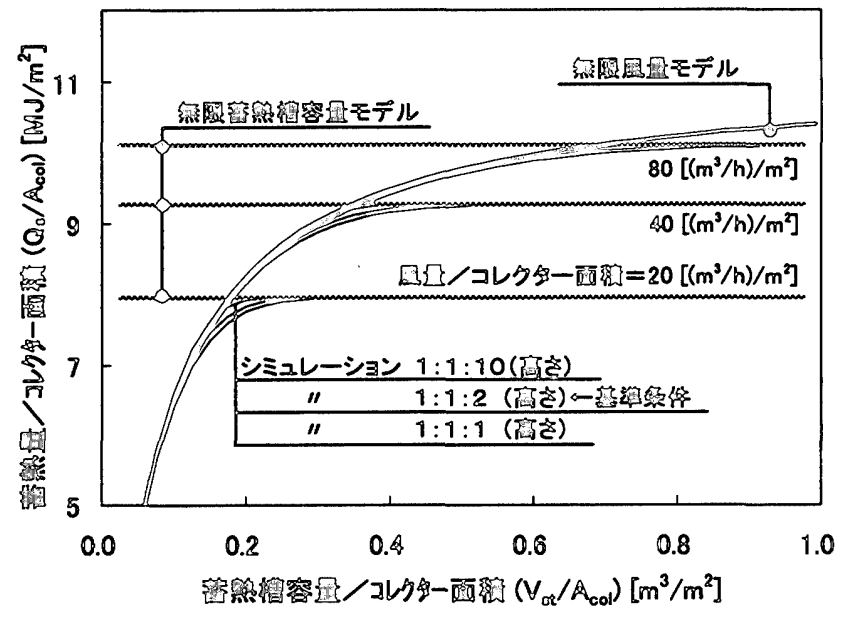

図 7 蓄熱量と蓄熱槽容量の関係への蓄熱槽形状の影響（コレクターB）

地域毎の気候を考虑し，長期間のシミュレーション等により検討す る必要があると考えている。また, 風量の設定については, システ ムのエネルギー性能に影響が大きいと考えられるファンでの消費電 力を考慮して設定する必要がある。

\section{6. 設定条件の影㟳}

前節までは，表 1 に示した条件の下で，コレクター単位面積あた クの最適蓄熱槽容量と風量の関係およびそのときの蓄熱量が, 比較 的簡単な関係式（式(24)および式(16)）で近似的に得られることを述べ てきた。ここでは, 表 1 の主要な設定条件が変化した場合の蓄熱量 とその近似の程度に対する各種パラメータの影響を検討した。表 3 には，表 1 の設定条件を基準の条件とし，それぞれのパラメータの みを変えた場合について, 蓄熱槽容量が式(24)から得られる最適蓄熱 槽容量である場合における, 式(16)から近似的に得られる蓄熱量およ びこの蓄熱量とシミュレーションによって計算される蓄熱量との誤 差を示している。ここでは，誤差を次式で定義した。

$$
\text { 誤差 }=\frac{\text { 蓄熱量 }(\text { 式 }(16)) \text { - 蓄熱量 (シミュレーション) }}{\text { 蓄熱量 }(\text { シュレーション })} \times 100[\%]
$$

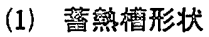

蓄熱槽形状に関しては，設定では槽高さが槽断面（正方形）の辺 の 2 倍としていたが, ここでは，1倍，10倍の蓄熱槽について検討 を行った。図 7 は, 各形状の蓄熱槽の蓄熱槽容量と蓄熱量の関係に 関するシミュレーションの結果および槽形状には影響されない極限 モデルの結果を示している。この図から, 蓄熱槽が熱媒空気の流れ

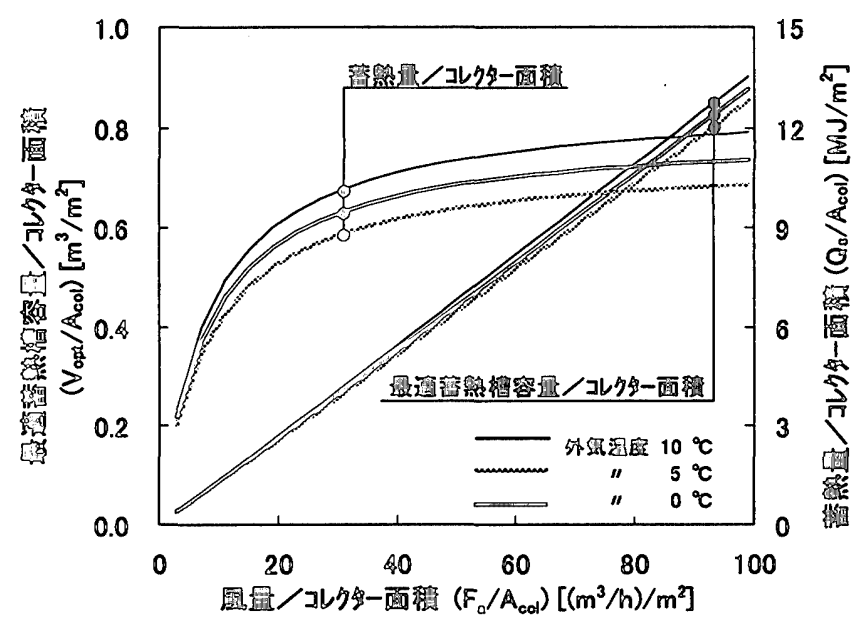

図 8 蓄熱量と最適蓄熱槽容量の関係人の外気温度の影響（コレクターB）

方向に長いものほど, 槽内の伝熱特性が向上するため, 結果的に極 限モデルの連立解の精度が高くなることが分かるが, 表 3 に示した 結果からも, 極端な槽形状でない限り, 蓄熱槽形状の精度への影響 は小さいと考えられる。

シミュレーションの結果としての蓄熱槽容量と蓄熱量の関係を, コレクター単位面積あたりについてこれまで図示してきたが, コレ クター面積が異なる場合には，実際には若干異なる結果となる。こ れは，蓄熱槽形状を固定しているため，コレクター単位面樍あたり の風量が同じであっても，コレクター面賽が大きくなるほど蓄熱槽 の単位断面積あたりの風量が大きくなり, 砕石蓄熱槽の伝熱モデル で用いている体積熱伝達率 $\left(h_{v}\right)$ が大きくなるために, 蓄熱槽内の 伝熱特性が相対的に向上するためである。しかしこれも，表 3 に示 した基準条件の場合の誤差との比較からは, 蓄熱量の近似の程度へ 与える影響は小さいといえる。

\section{(2) 外気温度の影響}

一般に, 日本の比較的温暖な地域では, 晴天日の外気温度は一日 で $10^{\circ} \mathrm{C}$ 程度は変動するが, 表 1 に示した基準条件では外気温度を 0 。 Cで終日一定であるとしている。外気温度が 0,5 および $10^{\circ} \mathrm{C} て ゙$ 終 日一定であるときの蓄熱量と最適蓄熱槽容量の風量との関係を図 8 に示す。この図から, 外気温度が異なる場合でも, 最適蓄熱槽容量 の変化は小さいといえる。しかし, 蓄熱量については変化が比較的 大きく, 表 3 の結果でも, 外気温度を $0^{\circ} \mathrm{C}$ とした基準条件の場合に 比較して, 外気温度が $5{ }^{\circ} \mathrm{C} て ゙ は 7.5 \%$ 程度, $10^{\circ} \mathrm{C}$ では $15.2 \%$ 程度增大 しており，その差は決して小さいとはいえないが，簡易な設計法と 
しては, 此較的温暖な地域では $0{ }^{\circ} \mathrm{C}$ 一定に設定しておけば安全側の 設計になると考えられる。ただし，熱損失係数が大きく集熱性能が 悪いコレクターを用いる場合は, 設定する外気温度について，その 日変動も含めて検討する必要があると考之られる。

（3）コレクターの方位角の影響

コレクターの方位角が $0^{\circ}$ (真南) からずれた場合は, 線形近似モ デルを導出する際に用いた仮定（式(22)）を満たさないことになる。 しかし, 方位角が $10^{\circ}$ 程度以内では, 表 3 に示したように, 方位角 が $\pm 10^{\circ}$ の場合の蓄熱量の誤差と基準条件の場合の誤差との差は小 さく,この程度のコレクターの方位角のずれの最適蓄熱槽容量への 影響は無視できる程度である。また，蓄熱量に関しても，方位が真 南である場合との差はー $1.0 \%$ 程度であり, 実際の方位角がー $10^{\circ} の$ 場合に，コレクターの方位を真南に想定して蓄熱量を計算したとし ても, 表 3 には示されていないが, シミュレーションによる蓄熱量 との䛊差は, 風量が $20\left(\mathrm{~m}^{3} / \mathrm{h}\right) / \mathrm{m}^{2}$ の場合で $4.7 \%$ 程度であり, コレク ターの方位角のずれの蓄熱量への影響も小さいといえる。

なお, 無限蓄熱槽容量モデルから得られる蓄熱量は限界蓄熱量で あるため, 線形近似モデル（式(24)）で求めた最適蓄熱槽容量におけ る実際の蓄熱量よりも若干大きめの蓄熱量となり，その䛊差は風量 等により異なるが,一般的な設計条件の範囲では, +7\%を超えるこ とはないと考えられる。具体的な設計手順としては，この蓄熱量の 誤差を考慮して, $10 \%$ 程度多めの蓄熱量を設定し, コレクタ一面積, 風量が設定できれば, 線形近似モデルおよび無限蓄熱槽容量モデル から，最適蓄熱槽容量を得ることができる。

\section{7.まとめ}

空気集熱式太陽熱暖房システムについて，蓄熱過程のみを对象と した場合の最適蓄熱槽容量について理論的な検討を行った。本研究 をまとめると以下の通りである。

(1) コレクターのモデルと砕石瞕熱槽の伝熱モデルを用いたシミュ レーションの結果から，ある風量での限界の蓄熱量をほぼ蓄熱で きる最小の蓄熱槽容量が，その風量での最適蓄熱槽容量であると した。

(2)この最適蓄熱槽容量と風量の関係とそのときの蓄熱量は, 無限 風量モデルと無限蓄熱槽容量モデルの連立解として近似的に得ら れる。

(3) 無限風量モデルと無限蓄熱槽容量モデルの連立解として得られ る最適蓄熱槽容量と風量の関係式が複雑であるにも関わらず，そ の関係はほぼ線形関係にあることから, 風量と最適蓄熱槽容量の 線形近似モデルを導いた。

(4) 線形近似モデルと無限蓄熱槽容量モデルから,コレクタ一面積, 風量が設定でき，式(17)から蓄熱開始・終了時刻およびその日の積 算日射量が設定できれば，容易に風量と最適蓄熱槽容量の関係と そのときの蓄熱量を近似的に求めることができる。

(5) 線形近似モデルと無限蓄熱槽容量モデルから得られる蓄熱量に 関する各種パラメータの影響を検討し，蓄熱槽形状，外気温度， コレクターの方位角の蓄熱量や最適蓄熱槽容量に与える影響は比 較的小さいことを明らかにした。
眍号

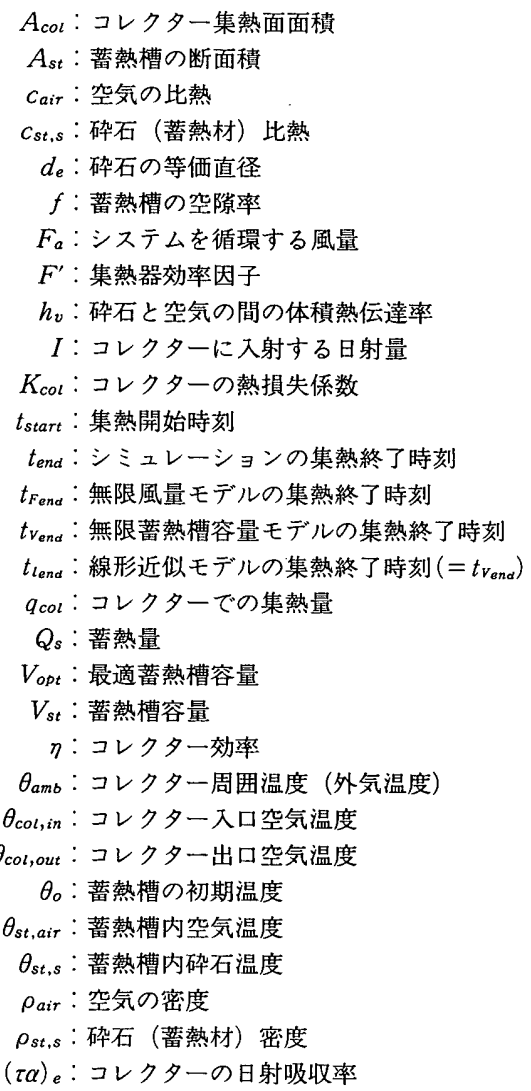

注

集熱効率因子 $F^{\prime}$ は, $F^{\prime}=$ (実際の集熱量) /(集熱板全面が集熱媒平均温度に 等しい場合の集熱量)で定義される"1)。

\section{参考文献}

1）住宅·建築省エネルギー機構, パッシブシステム住宅の設計, 丸善, pp.20, 1985

2) Duffie A.J. and Beckman W.A : Solar engineering of thermal processes, John Willey \& Sons, pp.485-511, 1980

3）東京天文台，理化年表，丸善，pp.110，1988

4）松尾陽, 他17名, 日本太陽エネルギ一学会, 太陽エネルギーハンドブッ ク, 初版, pp.1 45, 178, 1985

5）田中俊六, 鈴木定彦, 黒木 恵, 和気 隆：屋根一体形太陽熱-大気放射 冷却装置に関する研究 その 4 各種空気集熱器の実験, 日本建築学会大 会学術講演梗概集，pp. $569 \sim 570 ， 1982$

6）桐山宗久, 北野博亮, 相良和伸：空気集熱式太陽熱暖房システムにおける コレクター性能の風量の影響, 空気調和・衛生工学会学術講演会講演論文 集III, pp.1381 1384, 1999

7）木村健太郎, 岩田 剛, 北野博亮, 相良和伸：空気集熱式ソーラーコレク ターの動的熱特性のモデル化に関する研究, 日本建築学会大会学術講演梗 概集, D-3, pp.443 445, 1998

8) Schuumann T.E.W. : Heat transfer : A Liquid flowing through a porous prism, J. Franklin Inst. 208, pp.405-416,1929

9) Sagawa K. and Nakahara N.: Thermal Performance and Pressure Drop of Rock Beds with Large Storage Materials, Solar Energy, Vol. 47 No. 3, pp.157-163, 1991

10) Coutier J.P. and Farber E.A. : Tow Applications of a Numerical Approach of Heat Transfer Process within Rock Beds, Solar Energy, Vol. 29, pp.451-462, 1982

11）谷下市松 他 15 名, 日本太陽エネルギ一学会, 太陽エネルギーの基礎と応 用, pp.76, 1978

（1999年 5 月 17 日原稿受理，2000年 1 月 28 日採用決定） 